\title{
Effect of Aerobic and Anaerobic Treatment on Physico Chemical Characterization of Dairy Waste Water
}

\author{
Mansi Patel*, J.J. Patel and Bency Antony Kathayat \\ Maganbhai Park Soc Opp Gunatit Nagar, Nmai Mandir Road, Nnadiad 387002, \\ Kheda, Gujarat, India \\ *Corresponding author
}

\begin{abstract}
A B S T R A C T
Day by day the global environmental pollution is becoming one of the major problems. Dairy is one of the major agricultural industry components. The dairy industry effluent

\section{Keywords}

Aerobic, Anaerobic Treatment, Physico Chemical characterization Dairy waste water

Article Info

Accepted: 08 June 2018 Available Online: 10 July 2018 without any treatment plays significant risk for public health and environmental pollution mostly in developing countries because all milk is processed industrially. In the present study, physicochemical parameters like $\mathrm{pH}$, Chemical Oxygen Demand (COD), Biological Oxygen Demand (BOD),Oil and Grease, Total dissolve solid (TDS), Total Suspended Solid (TSS), Total Solid (TS), Chloride, Sulphate and Phosphate were taken for the detection of the pollution parameters in dairy industry wastewater. Total 10 samples before and after aerobic and anaerobic treatments were collected and subjected for analysis after a time period of 14 hours. Mean values were calculated from collected samples. There was $97 \%$ decrease in COD and Oil value, $98 \%$ decrease in BOD, $75 \%$ decrease in SS and $71 \%$ decrease in TDS value whereas there was a slight increase in $\mathrm{pH}$ value. The high BOD and COD value obtained by the analysis of dairy waste water indicates the presence of heavy load of organic metal in the sample of without aerobic and anaerobic treatment. The study revealed that dairy waste water is slightly alkaline in nature. The discharge of wastewater to the environment without any treatment plays significant risk for public health and environmental pollution.
\end{abstract}

\section{Introduction}

Most common processes like pasteurization, bottling, preparation of butter, cheese, milk powder, etc are carried out in the dairy industry. The environmental impact of these plants can be very high, especially due to effluent from milk processing unit which contains soluble organics, suspended solids, trace organics that releases gases, imparts colour, turbidity, bad taste and bad odor which promote eutrophication. The effluent discharged by raw milk quality control laboratories are more complex than the ones commonly generated by dairy plants because of the presence of the certain chemicals like sodium azide or chloramphenicol which are used for preserving milk before analysis (Shivsharan, 2013) 
The waste water may also contain pathogenic or non-pathogenic bacteria, organic particles such as faeces, hairs, food, vomit, paper, fibrils, plant materials and humus, inorganic particles such as grit, send, metal particles, ceramics etc., Soluble particles such as ammonia, road-salt, sea-salt, cyanide, hydrogen sulphide, thiocyanates, thiosulphates etc. Wastewater from dairy industry consists primarily of dilution of milk and milk products which impart a very high BOD, sometimes up to $1000 \mathrm{mg} / \mathrm{L}$. Wastewater from milk industries contains large quantities of fat, casein, lactose and inorganic salts, besides detergents, sanitizers etc used for washing (Kolhe et al., 2009) Dairy raw wastewater was characterized by high concentrations and fluctuations of organic matter and nutrient loads (Farizoglu and Uzuner, 2011).

Generally, we need to treat the effluent before flow in the environment. The degradation of environment results by the adverse effect of industrial waste on living organism and agriculture (Danalewich et al., 1998). So, first collection of waste water from the dairy, perform chemical analysis to reveal problem of safe disposal. Parameters like $\mathrm{pH}$, Chemical Oxygen Demand (COD), Biological Oxygen Demand (BOD), Oil and Grease, Total dissolve solid (TDS), Total Suspended Solid (TSS), Total Solid (TS), Chloride and Sulphate were taken. In this regard, the study was aimed for physicochemical characteristics of waste water generated from dairy industry with suitable treatment.

\section{Materials and Methods}

Ten samples of dairy waste water before and after the aerobic and anaerobic treatments were collected from effluent treatment plant of Amul Dairy and then physical and chemical analysis was carried out. Analysis were performed by using physicochemical parameters by (American Public Health Association APHA, 1998; Trivedy and Goel,
1984) the Physical parameter- Temperature, $\mathrm{pH}$, TS, TDS and TSS and Chemical parameter- Chloride, (DO), Chemical oxygen Demand (COD), Biological Oxygen Demand (BOD), Sulphate, Chloride, Oil and Grease.

\section{Results and Discussion}

The physico-chemical property of water plays an important role in the circulation of material and growth of microorganisms. Therefore, the physic-chemical analysis of water is most important aspect to determine the quality of lentic water ecosystems for its best uses to human and animal consumption, agricultural purpose and plants. Properties of water body related with physico-chemical nature reveals much about the metabolic and physical characteristics of the aquatic ecosystems. (Shriram, 2012) This also explores the hydro biological and ecological inter relationship.

\section{Colour}

The colour of untreated water was milky white, while colour of treated water was brown, while Ashish Tikariha and Omprakash Sahu, 2014 reviewed that waste water was light brown in colour. Light-to-medium grey colour of waste water is the characteristic of wastewaters that have undergone some degree of decomposition or that have been in the collection system for some time. This may be due to microbial activity sludge generation and resulted in dark grey or black color. The blackening of wastewater is often may be due to the formation of various sulphides, particularly, ferrous sulphide. This results when hydrogen sulphide produced under anaerobic conditions combines with divalent metal, such as iron, which may be present.

\section{pH}

$\mathrm{pH}$ gives an idea about the concentration of carbonate, bicarbonate and $\mathrm{CO}_{2}$ in water. Average $\mathrm{pH}$ of influent water was 6.4 whereas 
it was 7.6 in effluent water. This increase in pH may be attributed to alkalophilic microorganisms which are a part of indigenous micro-flora. These results were similar to the findings by Carawan et al., (1979); Monroy et al., (1995); Dhanam (2009) and Shaikh et al.,(2009) for dairy industrial effluents. Other studies conducted by Kolhe and Pawar (2011) also found $\mathrm{pH}$ of dairy effluents within $6-9.5$ range, which was quite similar to the values obtained in present study. Alkaline $\mathrm{pH}$ of dairy effluent was also observed by Medhat and Usama (2004); Khojare et al., (2005) and Gaikar et al., (2010). Presence of nutrients, high organic load and use of alkaline cleaning agents in dairy industry lead to its alkaline $\mathrm{pH}$.

\section{BOD}

BOD is the measure of amount $\mathrm{O}_{2}$ required by the microorganism to oxidize the organic content in water under aerobic condition. In the present study, influent was found high $1812 \mathrm{mg} / \mathrm{L}$ BOD, which was reduced to 30 $\mathrm{mg} / \mathrm{L}$ BOD after secondary treatment and similar results was reported by Kessler (1981) in which decrease of BOD was $92 \%$, where as 9033mg/L BOD was observed by Ashish Tikariha (2014) Similarly, high BOD 5570 $\mathrm{mg} / \mathrm{L}$ loads were also reported by Vishakha (2013) for dairy industry.

\section{COD}

COD is chemical oxidation processes that bring out the true picture of water quality. The COD test determines the oxygen required for chemical oxidation of organic matter without the help of chemical oxidant. The COD is a test, which is used to measure polluted waste water. In the present study, COD of influent was around $4814 \mathrm{mg} / \mathrm{L}$ and that of effluent was $105 \mathrm{mg} / \mathrm{L}$. Trivedi et al., (1986) observed COD value of textile industry ranges from 300 ppm to $2400 \mathrm{ppm}$. Comparatively Toldra et al., (1987) used the process to treat dairy wastewater with a COD of only $200-500 \mathrm{mg} / \mathrm{L}$ with COD removal of $80 \%$. Similarly, high COD $1486.8 \mathrm{mg} / \mathrm{L}$ load was also reported by Vishakha (2013) for dairy industry.

\section{Oil and grease}

The oil and grease content of domestic and certain industrial waste water is an important in handling and treatment of these materials for ultimate disposal. Oil and Grease may influence waste water system, if present in excessive amount. They may interfere with an aerobic and anaerobic biological process and lead to decreased waste water treatment efficiency. In the present study, oil and grease of untreated was $410 \mathrm{mg} / \mathrm{l}$ and treated was 8.9 $\mathrm{mg} / \mathrm{L}$ whereas Trivedi et al., (1986) reported oil and grease in textile industry effluent which varies from 230 to $1897 \mathrm{mg} / \mathrm{l}$.

\section{Chloride}

High concentration of chloride is a clear cut index of pollution. Direct discharge of untreated industrial waste increases the salt content in water. In the present study, Chloride content of influent was found to be $148 \mathrm{mg} / \mathrm{L}$ and effluent was $144 \mathrm{mg} / \mathrm{L}$ which was within the permissible limits of $600 \mathrm{mg} / \mathrm{L}$ according to the ISI standards, while Kolhe et al., (2008) observed that the effluent from sugar mill was having $205 \mathrm{mg} / \mathrm{L}$ in an untreated effluent chloride and the treated effluent was 170-180 mg/L.

\section{TDS}

The total solid concentration in waste effluent represents the colloidal form and dissolved species.

In the present study, the value of TDS for affluent was $1019 \mathrm{mg} /$ Land after treatment it was decreased upto $916 \mathrm{mg} / \mathrm{L}$ (Table 1). 
Table.1 Physico-chemical parameters of diary waste water

\begin{tabular}{|c|c|c|c|c|c|c|c|c|c|c|}
\hline $\begin{array}{l}\text { SAMPLE } \\
\text { NO }\end{array}$ & $\begin{array}{l}\text { SAMPLE } \\
\text { TYPE }\end{array}$ & $\mathrm{pH}$ & $\begin{array}{l}\mathrm{COD} \\
(\mathrm{mg} / \mathrm{L})\end{array}$ & $\begin{array}{lr}\text { Oil and } & \text { and } \\
\text { Grease } & (\mathrm{mg} / \mathrm{L})\end{array}$ & $\begin{array}{l}\text { TDS } \\
(\mathrm{mg} / \mathrm{L})\end{array}$ & $\begin{array}{l}\text { Chloride } \\
\text { (mg/L) }\end{array}$ & $\begin{array}{l}\text { BOD } \\
(\mathrm{mg} / \mathrm{L})\end{array}$ & $\begin{array}{c}\mathrm{TSS} \\
(\mathrm{mg} / \mathrm{L})\end{array}$ & $\begin{array}{c}\mathrm{TS} \\
(\mathrm{mg} / \mathrm{L})\end{array}$ & $\begin{array}{l}\text { SULPHATE } \\
\mathrm{mg} / \mathrm{L}\end{array}$ \\
\hline \multirow[t]{2}{*}{1} & Raw & 6.2 & 4742 & 416 & 990 & 158 & 1789 & 298 & 1299 & 90 \\
\hline & Treatment & 7.4 & 98 & 8.9 & 897 & 154 & 26 & 90 & 1007 & 12 \\
\hline \multirow[t]{2}{*}{2} & Raw & 6.1 & 4712 & 415 & 923 & 150 & 1876 & 312 & 1300 & 87 \\
\hline & Treatment & 7.1 & 109 & 8.8 & 900 & 147 & 26 & 87 & 1032 & 11 \\
\hline \multirow[t]{2}{*}{3} & Raw & 6.7 & 4746 & 378 & 1000 & 146 & 1800 & 325 & 1315 & 95 \\
\hline & Treatment & 7.5 & 110 & 9.4 & 956 & 142 & 22 & 98 & 1012 & 15 \\
\hline \multirow[t]{2}{*}{4} & Raw & 6.4 & 4689 & 382 & 1098 & 148 & 1856 & 315 & 1254 & 98 \\
\hline & Treatment & 7.1 & 104 & 7.9 & 987 & 145 & 33 & 92 & 1110 & 17 \\
\hline \multirow[t]{2}{*}{5} & Raw & 6.2 & 4700 & 374 & 1100 & 149 & 1890 & 317 & 1345 & 87 \\
\hline & Treatment & 7.8 & 118 & 9.2 & 924 & 146 & 34 & 91 & 1034 & 15 \\
\hline \multirow[t]{2}{*}{6} & Raw & 6.5 & 4087 & 421 & 1011 & 146 & 1729 & 328 & 1347 & 90 \\
\hline & Treatment & 8.1 & 98 & 9.1 & 947 & 142 & 31 & 93 & 1027 & 16 \\
\hline \multirow[t]{2}{*}{7} & Raw & 6.9 & 4100 & 445 & 1001 & 145 & 1800 & 320 & 1290 & 95 \\
\hline & Treatment & 8.0 & 100 & 9.3 & 942 & 143 & 34 & 90 & 999 & 17 \\
\hline \multirow[t]{2}{*}{8} & Raw & 6.0 & 4190 & 380 & 1010 & 146 & 1756 & 312 & 1321 & 93 \\
\hline & Treatment & 7.5 & 111 & 8.9 & 967 & 143 & 32 & 94 & 1056 & 12 \\
\hline \multirow[t]{2}{*}{9} & Raw & 6.7 & 4000 & 441 & 1045 & 149 & 1798 & 370 & 1245 & 89 \\
\hline & Treatment & 7.7 & 99 & 9.0 & 978 & 146 & 36 & 91 & 1009 & 14 \\
\hline \multirow[t]{2}{*}{10} & Raw & 6.4 & 4078 & 456 & 1012 & 143 & 1826 & 345 & 1267 & 91 \\
\hline & Treatment & 7.5 & 104 & 9.3 & 965 & 141 & 27 & 89 & 1045 & 16 \\
\hline \multirow[t]{2}{*}{ Mean } & Raw & 6.4 & 4814 & 410 & 1019 & 148 & 1812 & 324 & 1298 & 91.5 \\
\hline & Treatment & 7.6 & 105 & 8.9 & 946 & 144 & 30 & 91 & 1033 & 14.5 \\
\hline $\begin{array}{l}\text { I.S.I. } \\
\text { Value } \\
\text { (mg/L) }\end{array}$ & -- & $\begin{array}{c}6.5 \\
\text { to } \\
8.0\end{array}$ & 250 & 10 & 1500 & 600 & 50 & $\begin{array}{c}\text { Not } \\
\text { above } \\
450\end{array}$ & 1100 & $\begin{array}{c}\text { Not above } \\
1000\end{array}$ \\
\hline
\end{tabular}

On the contrary, Shaikh et al.,(2009) obtained very high value of TDS i.e1.9 ppt; similar higher values were obtained by other workers like Khojare et al.,(2005), Dharam (2009) and Gaiker et al.,(2010) for treated waste water from milk processing unit. The probable reason for the fluctuation of value of total solid and subsequent the value of dissolved solids due to content collision of these colloidal particles. The rate of collision of aggregated process is also influenced by $\mathrm{pH}$ of these effluents.

\section{TSS}

BIS has not set any limit of total suspended solid for drinking water. Their presence in water sample causes depletion of oxygen level. Devi (1980) reported total plankton, which showed a sterkling parallelism with suspended solids. In the present study suspended solids content of untreated effluent was $324 \mathrm{mg} / \mathrm{L}$ and that of treated effluent was $91 \mathrm{mg} / \mathrm{L}$. Similar results was reported by Kolhe A.S. and Pawar V. P. (2011) that was $310 \mathrm{mg} / \mathrm{L}$ for untreated and $80 \mathrm{mg} / \mathrm{L}$ for treated water. Avsan and Rao (2001) observed the TSS in sugar mill effluents is 220 to 790 mg/lit.

\section{TS}

The total solids are sum of the values of the total dissolved solids and that suspended solids. The solid varies in proportions to temperature and rarely varied inversely to the water level. In effluent, total solids, total dissolved solids, total suspended solids are 
composed mainly of carbonates, bicarbonates, chlorides, sulphate, phosphate, nitrate, $\mathrm{Ca}$, $\mathrm{Mg}, \mathrm{Na}, \mathrm{K}, \mathrm{Mn}$ and organic matter. In the present study the value of total solid present in untreated effluent was $1298 \mathrm{mg} / \mathrm{L}$ and treated effluent was $1033 \mathrm{mg} / \mathrm{L}$, whereas Kolhe and Pawar (2011) reported the value of untreated effluent which $1310 \mathrm{mg} / \mathrm{L}$ and treated effluent was $560 \mathrm{mg} / \mathrm{L}$

\section{Sulphate}

Sulphate is one of the major cation occurring in natural water. Sulphate being a stable, highly oxidized, soluble form of sulphur. Sulphate, itself has never been a limiting factor in aquatic systems. The normal levels of sulphate are more than adequate to meet plants need. In the present study, the values of sulphate for treated effluent was $91.5 \mathrm{mg} / \mathrm{L}$ to $14.5 \mathrm{mg} / \mathrm{L}$ whereas Kolhe et al., (2008) observed the sugar mill effluent was having sulphate of untreated effluent is $660 \mathrm{mg} / \mathrm{l}$ and treated effluent showed $220 \mathrm{mg} / \mathrm{L}$ and the values of sulphate for untreated effluent was $395 \mathrm{mg} / \mathrm{l}$ and that of treated effluent was 75 mg/l by Kolhe and Pawar (2011)

In conclusion, the objective of this study was to investigate the major pollutant of wastewater in dairy industry by studying the physicochemical characteristics of waste water generated from dairy industry with suitable treatment. Waste water from dairy industries contain mainly organic and biodegradable materials that can disrupt aquatic and terrestrial ecosystems, hence the importance of carrying out a treatment as a starting point in order to optimize a simple and economic method for safe disposal.

BOD and COD value were quite higher in the waste water indicates its polluted nature. Waste water was rich in protein and fat content. MPN value was higher which indicates the polluted nature of waste water.
All the studied physico-chemical and Biological parameter proved that the water discharged from milk processing unit is of polluted nature. Its disposal without any treatment in to fresh water body may impose the danger of eutrophication as well as serious problems of health and hygiene. To avoid the environmental pollution and to protect public health, wastewater treatment systems are recommended for dairy industry for the preservation of the ecological balance.

\section{References}

APHA 1998. Standards methods for the examination of water and waste water. American Public Health Association, $19^{\text {th }}$ edition, pp. (1-1)-10-150.

Devi, A. 1980 Ecological studies of limon plankton of three fresh water body, Hyderabad. Ph.D. thesis Osmania University, Hyderabad.

Tikariha Ashish, Sahu Omprakash 2014, Study of Characteristics and Treatments of Dairy Industry Waste Water. Journal of Applied \& Environmental Microbiology, Vol.2, No.1, 16-22

Avasan, M.Y. and Rao, R.S. 2001. Effect of Sugar Mill Effluent on Organic Resources of Fish, Poll. Res., 20(2):167-171.

Carawan, R.E., Chambers J.V., Zall J.V. 1979. Seafood water and wastewater management. North Carolina Agricultural Extension Services, Raleigh, NC.

Dhanam, S. 2009.Effect of dairy effluent on seed germination, seedling growth and biochemical parameters in Paddy. Bot. Res. Int., 2:61-63.

Danalewich, J.R., Papagiannis, T.G., Belyea, R.L., Tumbleson, M.E. and Raskin, L. 1998.Characterization of Dairy Waste Streams, Current Treatment Practices and Potential for Biological Nutrient 
Removal, Water Res., 32:3555-3568

Farizoglu, B., and Uzuner, S., 2011. The investigation of dairy industry waste water treatment in a biological high performance membrane system. Biochem. Eng. J., 57: 46-54

Gaikar, R.B., Uphade , B.K., Gadhave , A.G., Kuchekar S.R. 2010. Effect of dairy effluents on seed germination and early seedling growth of soybeans. Rasayan J.Chem.,3(1):137-139

Kolhe, A.S., Ingale, S.R. and Sarode, A.G., 2008. Physico-chemical analysis of sugar mill effluents. Int. Res. Jr. Sodh, Samiksha and Mulyankan4(I): 307311

Kessler, H.G. (Ed.) 1981. Food Engineering and Dairy Technology; Verlag: Freisburg, Germany.

Kolhe , A.S., and Pawar, V.P.. 2011. Environmental Sciences Physico Chemical Analysis of Effluents fromDairy Industry,Recent Res. in Sci.Technol., 3(5):29-32.

Kolhe, A.S., Ingale, S.R. and Bhole. R.V. 2009.Effluents of Diary Technology, Int. Res. Jr. Sodh, Samiksha and Mulyankan, 5(II): 459-461.

Khojare, A.S., Patil , M.R., Sarode, A.R., Wasnik, P.G.. 2002. Membrane process: An emerging solution for effluent treatment in dairy and food plant. Proceedings of UGC Sponsored National Conference on 'Hydrochemical, Bio - chemical Studies and Environmental Pollution' Aurangabad.

Medhat, M.A., Usama, F.M. 2004.Anaerobic digestion technology for industrial wastewater treatment. Eighth International Water Technology
Conference, Alexandria

Monroy,H.O., $\quad$ Vazquezz,M., Derramadero,J.C. and J.P. Guyot. 1995. Anerobic-aerobic treatment of Dairy waste water with national technology in Maxico: the case of "El Sanz", 3rd international symposium on waste management problems in Agro-industries, Mexico city, 4-6: 202-209.

Shaikh,A.M., and Mandre, P.N. 2009. Seasonal study of physic-chemical parameters of drinking water in Khed (Lote) industrial area. Shodh,Samiksho aur Mulyankan. Int. Res.J.,11(7):169-171.

Shriram, Jan. 2012, Hydro-chemical monitoring of drinking water in kadi river at nimgaon choba project in beed 3(1):133 - 137.

Trivedy, R K and Goel, P K 1984. Practical Methods in Ecology and Environmental Science.By -Environmedia publications Karad. P-69-85.

Toldra, F.; Flors, A.; Lequerica, J.L.; Vall S.S. 1987 Fluidized bed anaerobic biodegradation of food industry wastewaters. Biol. Wast., 21, $55-61$.

Trivedi, R.K., Khatavkar, S.B. and Goel, P.K. 1986. Characterization, Treatment and Disposal of Waste Water in a Textile Industry, Ind. Poll. Cont., 2(1): 1-12.

Shivsharan, V.S., Kulkarni, S. W. and Wani, M. April 2013 "Physicochemical Characterization of Dairy Effluents," International Journal of Life Sciences Biotechnology and Pharma Research, Vol. 2, No. 2, pp. 182-191.

\section{How to cite this article:}

Mansi Patel, J.J. Patel and Bency Antony Kathayat. 2018. Effect of Aerobic and Anaerobic Treatment on Physico Chemical Characterization of Dairy Waste Water. Int.J.Curr.Microbiol.App.Sci. 7(07): 827-832. doi: https://doi.org/10.20546/ijcmas.2018.707.101 